\title{
Assessment of Medication Adherence to JNC-7 Guidelines and Risk Factors for Hypertension in a South Indian Tertiary Care Hospital
}

\author{
Uday Bhaskar Narra1, Ravindrababu Pingili1,2, Sri Varsha Reddy Chinnam', Prardhana Devi Datla1, \\ Sree Varsha Potluri', Naveen Babu Kilaru*
}

${ }^{1}$ Department of Pharmacy Practice, KVSR Siddhartha College of Pharmaceutical Sciences, Vijayawada, Andhra Pradesh, INDIA

${ }^{2}$ Department of Pharmacology, KVSR Siddhartha College of Pharmaceutical Sciences, Vijayawada, Andhra Pradesh, INDIA

\begin{abstract}
Objective: The objective of the study was to assess the drug utilization pattern, medication adherence to Joint National Committee (JNC-7) treatment guidelines and risk factors for hypertension (HTN) in a south Indian tertiary care teaching hospital. Methods: A prospective study was conducted on 1000 subjects (with or without hypertension) from November 2015 to April 2016 in a general medicine department. Drug utilization pattern, medication adherence was assessed by comparing with the JNC-7 guidelines and the odds ratios were calculated in univariate regression analysis for risk factors. Results: Stage 1 hypertension (47.30\%) was most predominant than stage 2 hypertension (24.28\%) and hypertension emergency $(12.23 \%)$ according to the SBP of JNC-7 guidelines. Hypertension was significantly higher in the subjects of age above 40 years $(92.6 \%, P<0.0001)$, married $(99.6 \%, P<0.0001)$, educated (59.5\%, $\mathrm{P}=0.066)$, known family history (father, $\mathrm{P}=0.009$; mother, $P<0.0001$; father and mother, $\mathrm{P}<0.0001)$, physical inactivity $(74.8 \%, P<0.001)$, monthly income above Rs. 10,000 (34.5\%, $P<0.0001$ ), co-morbidities (diabetes, $P<0.0001$; history of cardiovascular diseases, $P<0.0001$; chronic kidney disease, $P<0.0001$ ), alcohol consumption $(19.2 \%, P=0.007)$, smoking $(23 \%, P=0.0005)$, tea consumption (twice or more per day, $\mathrm{P}=0.027$ ), and intake of junk foods (thrice or more in a week, $P<0.0001)$ than normotensive subjects. Angiotensin receptor blockers $(17.98 \%)$ are most widely prescribed drugs followed by calcium channel blockers $(10.07 \%)$ and ß-blockers (6.29\%) in monotherapy (38.63\%). Angiotensin receptor blocker + diuretic combination (24.64\%) was mostly used in two drug combination therapy $(36.11 \%)$. The overall rate of adherence was $24.9 \%$ (Pre hypertension, $P<0.01$ ); $80.3 \%$ (Stage 1 hypertension, $P<0.001$ ); $73.93 \%$ (Stage 2 hypertension, $P<0.001$ ) and $50 \%$ (Hypertension emergency, $P<0.05)$. Univariate regression analysis showed that age (above 40 years), female gender, married, widowed, generalized obesity, moderate to high economic status (Above 10,000/month), family history, diabetes, history of cardiovascular diseases, chronic kidney disease, physical inactivity, smoking, alcohol consumption and junk food (weekly thrice or more, odds ratio: $17.69,95 \%$ confidence interval: 2.373-131.8, $P<0.0001$ ) intake were significantly associated with HTN. Conclusion: The present study results suggested that medication adherence to JNC-7 was optimal. Junk foods, age (above 60 years), diabetes, alcohol, smoking, marital status and high economic status are the main risk factors for hypertension.

Key words: Odds Ratio, Hypertension, Risk Factors, Medication Adherence, Junk Foods, JNC-7.
\end{abstract}

DOI: 10.5530/ijopp.10.2.17

Address for correspondence: Dr. K. Naveen Babu, Professor, KVSR Siddhartha College of Pharmaceutical Sciences, Vijayawada, Andhra Pradesh, INDIA. Phone no: +91-9666212999 E-mail: naveenbabukvsr@gmail com

\section{INTRODUCTION}

Hypertension (HTN) is a major public health problem and is a leading risk fac- tor for non-communicable diseases globally and is responsible for $13 \%$ of global

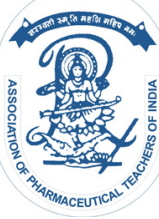

www.ijopp.org 
deaths. ${ }^{1,2}$ The age, obesity, excess salt intake, tobacco use, lack of physical activity and excess alcohol consumption are the major risk factors for HTN. ${ }^{3}$ In adults, HTN is a major risk factor for cardiovascular disease (coronary heart disease and stroke), chronic renal disease and diabetes. Evidence from large clinical trials now suggests that lowering blood pressure effectively prevents these adverse outcomes. ${ }^{4}$

Many guidelines (AHA, American Heart Association; ACC, American College of Cardiology; CDC, Centers for Disease Control and Prevention; ADA, American Diabetes Association and JNC-7, Seventh Report of the Joint National Committee on Prevention, Detection, Evaluation, and Treatment of High Blood Pressure; ESH, European Society of Hypertension; ESC, European Society of Cardiology) exist for the management of hypertension. ${ }^{5}$ But the most widely used recommendations are $\mathrm{ADA}$ and JNC-7.., 7 The overall principles common to these guidelines are to implement life style modifications in addition to pharmacotherapy to control BP in patients with hypertension. Patient's optimal adherence with antihypertensive drug therapy is essential for preventing serious complications with hypertension over the long term. JNC-7 guidelines are considered as the "gold standard" for the management of hypertension.

Therefore, the present study was planned to assess the medication adherence to JNC-7 guidelines and risk factors for hypertension in a south Indian tertiary teaching hospital to improve the patients care because suboptimal adherence leads to adverse clinical outcomes.

\section{MATERIALS AND METHODS}

The present prospective study was carried out at in and outpatients department of Dr. Pinnamaneni Siddhartha Institute of Medical Sciences and Research Foundation, Vijayawada, Andhra Pradesh, South India. The study was initiated after approval by the Institutes Ethical Review Committee, KVSR Siddhartha College of Pharmaceutical Sciences (SCOPS), Vijayawada, India. KVSR SCOPS was recognized by All India Council of Technical Education (AICTE) and Pharmacy Council of India (PCI), New Delhi, Govt. of India. The protocol approval number is KVSRSCOPS/IEC/2015/002.

\section{Selection of Participants}

Patients of either sex diagnosed with or without hypertension of any duration (as per JNC-7 guidelines) and willing to participate were included in the study. A total of 1000 patients (556 patients with hypertension and 446 patients without hypertension) were enrolled in the study. Based on the JNC-7 guidelines, the hypertensive patients were classified into prehypertension (SBP, 120-139 $\mathrm{mmHg}$; DBP, 80-89 $\mathrm{mmHg}$ ), stage 1 hypertension (SBP, 140-159 $\mathrm{mmHg}$; DBP, $90-99 \mathrm{mmHg}$ ), stage 2 hypertension (SBP, 160-179 mmHg; DBP, 100-119 $\mathrm{mmHg}$ ) and hypertension emergency (SBP, $\geq 180 \mathrm{mmHg}$; DBP, $\geq 120 \mathrm{mmHg}$ ).

\section{Data Collection}

Physicians were requested to report the clinical and biochemical data not exceeding 6 months before the observation. Biochemical parameters were derived from the latest laboratory investigation reports documented in the clinical records. A total of 556 prescriptions were collected from hypertension patients. Each prescription includes the drug, quantity, duration, and date of dispensing. Each antihypertensive medication was categorized into one of the following classes: thiazide-type diuretics, angiotensin converting enzyme inhibitors (ACEIs) or angiotensin receptor blockers (ARBs), calcium channel blockers (CCBs), $\beta$-blockers and other antihypertensive agents.

Medication Adherence was assessed by comparing with JNC-7 treatment guidelines. The information regarding sociodemographics (age, sex, marital status, education, family history of known hypertension, BMI, monthly income and co-morbid conditions) and lifestyle characteristics (residential area, alcohol consumption, smoking status, food habits, stress at work place and physical activity) were collected by interviewing the participant to identify the possible risk factor. All the relevant data were collected in a predesigned paper case record form with prior consent of the participant.

\section{Statistical analysis}

Statistical analyses were performed using SPSS ver$\operatorname{sion}^{20}$ (SPSS Inc., Chicago, IL, USA) and Graph Pad Prism 5.0 software (San Diego, CA). Estimates were expressed as mean $\pm \mathrm{SD}$. One-way analysis of variance or Student's ' $t$ '-test were used to compare groups for continuous variables and $\chi^{2}$-test was used to compare proportions between the two groups. Univariate logistic regression analysis was used to examine the association between various exposures (age, gender, place of residence, generalized obesity, cigarette smoking, alcohol consumption, income status and literacy level) and outcome (HTN). P-value $<0.05$ was considered significant. 
Table 1: Clinical characteristics of patients with hypertension

\begin{tabular}{|c|c|}
\hline Variable & Patients with HTN $(\mathrm{N}=556) \%$ \\
\hline \multicolumn{2}{|l|}{ Gender } \\
\hline Male & $268(48.256)$ \\
\hline Female & $288(51.743)$ \\
\hline \multicolumn{2}{|l|}{ Age (Years) } \\
\hline Mean \pm SD & $57.08 \pm 11.37$ \\
\hline $0-20$ & 0 \\
\hline $21-40$ & $41(7.374)$ \\
\hline $41-60$ & $313(56.294)$ \\
\hline Above 61 & $202(36.330)$ \\
\hline \multicolumn{2}{|l|}{ Body weight (Kg) } \\
\hline Mean \pm SD & $72.573 \pm 13.224$ \\
\hline \multicolumn{2}{|c|}{ Type of hypertension according to SBP as per JNC-7 } \\
\hline Prehypertension (120-139 mmHg) & $90(16.187)$ \\
\hline Stage 1 hypertension (140-159 mmHg) & $263(47.302)$ \\
\hline Stage 2 hypertension $(160-169 \mathrm{mmHg})$ & $135(24.280)$ \\
\hline Hypertension emergency ( $\geq 180 \mathrm{mmHg}$ ) & $68(12.230)$ \\
\hline \multicolumn{2}{|c|}{ Type of hypertension according to DBP as per JNC-7 } \\
\hline Prehypertension (80-89 mmHg) & $121(21.762)$ \\
\hline Stage 1 hypertension $(90-99 \mathrm{mmHg})$ & $230(41.366)$ \\
\hline Stage 2 hypertension $(100-119 \mathrm{mmHg})$ & $183(32.913)$ \\
\hline Hypertension emergency ( $\geq 120 \mathrm{mmHg}$ ) & $22(3.956)$ \\
\hline \multicolumn{2}{|l|}{ Co-morbidities } \\
\hline Diabetes mellitus & $211(38.0)$ \\
\hline History of CVDs & $13(2.3)$ \\
\hline Thyroid disorders & $3(0.5)$ \\
\hline Diabetes and CVDs & $51(9.2)$ \\
\hline Diabetes and thyroid & $28(5.0)$ \\
\hline Diabetes and other & $83(14.9)$ \\
\hline CVD and Other & $65(11.7)$ \\
\hline PCOS & $4(0.7)$ \\
\hline Chronic kidney disease & $21(3.8)$ \\
\hline Others & $45(8.1)$ \\
\hline \multicolumn{2}{|l|}{ Duration of hypertension (Years) } \\
\hline$<5$ & $290(52.158)$ \\
\hline $5-10$ & $153(27.517)$ \\
\hline$>10$ & $113(20.323)$ \\
\hline \multicolumn{2}{|l|}{ Frequency of health check ups } \\
\hline Monthly once & $176(31.654)$ \\
\hline $1-3$ months & $88(15.827)$ \\
\hline 4-6 months & $129(23.201)$ \\
\hline$>6$ months & $163(29.316)$ \\
\hline \multicolumn{2}{|l|}{ Following HTN education } \\
\hline Yes & $326(58.633)$ \\
\hline No & $230(41.366)$ \\
\hline
\end{tabular}

HTN, Hypertension; SBP, Systolic Blood Pressure; DBP, Diastolic Blood Pressure; CVDs, Cardiovascular Diseases; PCOS, Poly Cystic Ovarian Syndrome; SD, Standard Deviation; JNC, Joint National Committee. 


\section{RESULTS}

A total of 1000 subjects (556 with hypertension and 444 without hypertension) were included in the study and the clinical characteristics of hypertension were presented in Table 1 . Hypertension was significantly higher in females $(51.74 \%)$ than in males $(48.25 \%)$. The mean \pm SD age was $57.08 \pm$ 11.37 years and the mean \pm SD body weight was $72.57 \pm 13.22 \mathrm{Kg}$ in hypertension. Stage 1 hypertension $(47.30 \%)$ was most predominant than stage 2 hypertension $(24.28 \%)$ and hypertension emergency $(12.23 \%)$ according to the SBP of JNC-7 guidelines. Diabetes mellitus (38.0\%) and cardiovascular diseases $(11.7 \%)$ are the most common co-morbidities in hypertension patients followed by chronic kidney diseases (3.8\%). Most of the patients (58.63\%) are strictly following and aware of hypertension education.

Tables 2 and 3 shows the socio demographic and life style characteristics of subjects with and without HTN, respectively. The prevalence of HTN was significantly higher in females $(51.8 \%, P<0.05)$ than in males. Hypertensive subjects were older (mean \pm SD age was $57 \pm 11.46$ years) and had a greater BMI $(>25 \mathrm{~kg} / \mathrm{m} 2, P<0.0009)$.

Hypertension was significantly higher in the subjects of age above 40 yrs $(92.6 \%, \mathrm{P}<0.0001)$, married $(99.6 \%, P<0.0001)$, educated $(59.5 \%, P=0.066)$, known family history (father, $P=0.009$; mother, $P<0.0001$; father and mother, $P<0.0001$ ), physical inactivity $(74.8 \%, P<0.001)$, monthly income above Rs. 10,000 (34.5\%, $P<0.0001$ ), co-morbidities (diabetes, $P<0.0001$; history of cardiovascular diseases, $P<0.0001$; chronic kidney disease, $\mathrm{P}<0.0001$ ), alcohol consumption (19.2\%, $\mathrm{P}=0.007)$, smoking $(23 \%$, $\mathrm{P}=0.0005$ ), tea consumption (twice or more per day, $\mathrm{P}=0.027$ ), and intake of junk foods (thrice or more in a week, $\mathrm{P}<0.0001$ ) than normotensive subjects. Family history of known hypertension (brother and sister, $\mathrm{P}=0.881)$, thyroid disorders $(\mathrm{P}=1.000)$, PCOD $(\mathrm{P}=1.000)$, urban residence $(\mathrm{P}=0.319$, food (vegetarian and non-vegetarian, $\mathrm{P}=0.574$ ), coffee consumption $(\mathrm{P}=0.423)$, fruits (thrice or more in a week, $\mathrm{P}=0.149$ ) and soft drinks (thrice or more in a week, $P=0.171$ ) are not significantly associated with the prevalence of hypertension.

Drug utilization pattern was assessed and presented the results in Table 4. Angiotensin receptor blockers $(17.98 \%)$ are most widely prescribed drugs followed by calcium channel blockers $(10.07 \%)$ and $\beta$-blockers $(6.29 \%)$ in monotherapy (38.63\%). Angiotensin receptor blocker + diuretic combination (24.64\%) was mostly used in two drug combination therapy $(36.11 \%)$. In triple combination $(6.8 \%)$ therapy, the most prescribed combination was calcium channel blockers + angiotensin receptor blockers + Diuretics (3.59\%). ARBs + Diuretics + $\beta$-blockers + CCBs combination $(1.43 \%)$ was most prescribe combination in four drug combination therapy (2.14\%). Antihypertensive medication was compared with JNC-7 guidelines for its optimal adherence and the results present in the Table 5. The overall rate of adherence was $24.9 \%$ (Pre hypertension, $P<0.01$ ); $80.3 \%$ (Stage 1 hypertension, $P<0.001$ ); $73.93 \%$ (Stage 2 hypertension, $P<0.001$ ) and 50\% (Hypertension emergency, $P<0.05$ ).

Univariate regression analysis was performed to determine the odds ratios for the modifiable and no modifiable risk factors for hypertension (Table 6).

The analysis showed that age (between 40-60) years (odds ratio: 3.638, 95\% confidence interval: 2.449-5.405, $P<0.0001$ ), age above 60 years (odds ratio: 5.689 , 95\% confidence interval: 3.693-8.763, $P<0.0001$ ), female gender (odds ratio: $1.287,95 \%$ confidence interval: 1.002-1.653, $\mathrm{P}=0.048)$, married (odds ratio: 13.13, 95\% confidence interval: 3.059 56.31, $P<0.0001$ ), widowed (odds ratio: $101.5,95 \%$ confidence interval: 15.55-662.3, $P<0.0001)$, BMI (odds ratio: 1.529, 95\% confidence interval: 1.1891.967, $\mathrm{P}=0.0009$ ), moderate to high economic status (odds ratio: 4.677, 95\% confidence interval: 3.281-6.666, $P<0.0001$ ), family history (father, odds ratio: $1.698,95 \%$ confidence interval: 1.150 2.507, $\mathrm{P}=0.009$; mother, odds ratio: 2.816 , $95 \%$ confidence interval: 1.675-4.732, $P<0.0001$; both mother and father, odds ratio: 3.238 , 95\% confidence interval: 1.747-6.001, $P<0.0001$ ), diabetes mellitus (odds ratio: 6.695, 95\% confidence interval: 4.038-11.10, $P<0.0001$ ), history of cardiovascular diseases (odds ratio: $3.830,95 \%$ confidence interval: 1.393-10.53, $\mathrm{P}=0.006$ ), co-existence of diabetes and thyroid (odds ratio: 2.750 95\% confidence interval: 1.357-5.572, $\mathrm{P}=0.007$ ), chronic kidney disease (odds ratio: 10.83 , 95\% confidence interval: $3.429-34.19$, $P<0.0001$ ), physical inactivity (odds ratio: 1.906, 95\% confidence interval: 0.930-1.538, P<0.0001), smoking (odds ratio: $1.809,95 \%$ confidence interval: 1.298-2.520, $\mathrm{P}=0.0005$ ), alcohol consumption (odds ratio: $1.618,95 \%$ confidence interval: 1.141-2.294, $\mathrm{P}=0.0076)$ and junk food (weekly thrice or more) intake (odds ratio: 17.69, 95\% confidence interval: 2.373-131.8, $P<0.0001)$ were significantly associated with HTN. 
Table 2: Sociodemographic characteristics of patients with and without hyper-

tension.

\begin{tabular}{|c|c|c|c|}
\hline Variable & $\begin{array}{c}\text { Patients without HTN }(\mathrm{N}= \\
444) n(\%)\end{array}$ & $\begin{array}{l}\text { Patients with HTN } \\
(\mathrm{N}=556) \mathrm{n}(\%)\end{array}$ & P-value ${ }^{a}$ \\
\hline \multicolumn{4}{|l|}{ Gender } \\
\hline Male & $242(54.5)$ & $268(48.2)$ & Ref \\
\hline Female & $202(45.5)$ & $288(51.8)$ & 0.048 \\
\hline \multicolumn{4}{|l|}{ Age } \\
\hline Mean \pm SD & $52.621 \pm 6.485$ & $57 \pm 11.46$ & 0.03 \\
\hline Below 40 years & $112(25.2)$ & $41(7.4)$ & Ref \\
\hline Above 40 years & $332(74.8)$ & $515(92.6)$ & $<0.0001$ \\
\hline \multicolumn{4}{|l|}{ Marital Status } \\
\hline Unmarried & $21(4.7)$ & $02(0.4)$ & Ref \\
\hline Married & $423(95.3)$ & $554(99.6)$ & $<0.0001$ \\
\hline \multicolumn{4}{|l|}{ Education } \\
\hline Uneducated & $154(34.7)$ & $225(40.5)$ & Ref \\
\hline Educated & $290(65.3)$ & $331(59.5)$ & 0.066 \\
\hline \multicolumn{4}{|l|}{ Family History } \\
\hline No family history & 339 (76.3) & 344 (61.9) & Ref \\
\hline Father & $47(10.6)$ & $81(14.5)$ & 0.009 \\
\hline Mother & $21(4.7)$ & $60(10.8)$ & $<0.0001$ \\
\hline Brother \& sister & $23(5.2)$ & $25(4.5)$ & 0.881 \\
\hline Father \& mother & $14(3.2)$ & $46(8.3)$ & $<0.0001$ \\
\hline \multicolumn{4}{|l|}{ Body mass index (BMI) } \\
\hline$<25 \mathrm{~kg} / \mathrm{m} 2$ & $260(58.6)$ & $267(48.0)$ & Ref \\
\hline$>25 \mathrm{~kg} / \mathrm{m} 2$ & $184(41.4)$ & $289(52.0)$ & $<0.0009$ \\
\hline \multicolumn{4}{|l|}{ Nature of work } \\
\hline Physically inactive & $42(9.4)$ & $73(13.1)$ & Ref \\
\hline Daily labour & $78(17.6)$ & $100(18.0)$ & 0.226 \\
\hline House wife & $140(31.5)$ & $197(35.4)$ & 0.379 \\
\hline Private job & $118(26.6)$ & $118(21.2)$ & 0.022 \\
\hline Business & $27(6.1)$ & $11(2.0)$ & 0.0003 \\
\hline Govt job & $39(8.8)$ & $57(10.3)$ & 0.571 \\
\hline \multicolumn{4}{|l|}{ Socioeconomic status } \\
\hline Lower class & 399 (89.9) & $364(65.5)$ & Ref \\
\hline Upper class & $45(10.1)$ & $192(34.5)$ & $<0.0001$ \\
\hline \multicolumn{4}{|l|}{ Co-morbidities } \\
\hline No & $66(14.9)$ & $32(5.8)$ & Ref \\
\hline Diabetes mellitus & $65(14.6)$ & $211(38.0)$ & $<0.0001$ \\
\hline History of CVDs & $7(1.6)$ & $13(2.3)$ & 0.010 \\
\hline Thyroid disorders & $6(1.3)$ & $3(0.5)$ & 1.000 \\
\hline Diabetes and CVDs & $53(11.9)$ & $51(9.2)$ & 0.022 \\
\hline Diabetes and thyroid & $21(4.7)$ & $28(5.0)$ & 0.007 \\
\hline Diabetes and other & $98(22.1)$ & $83(14.9)$ & 0.041 \\
\hline CVD and Other & $10(2.3)$ & $65(11.7)$ & $<0.0001$ \\
\hline PCOS & $8(1.8)$ & $4(0.7)$ & 1.000 \\
\hline Chronic kidney disease & $4(0.9)$ & $21(3.8)$ & $<0.0001$ \\
\hline Others & $106(23.9)$ & $45(8.1)$ & 0.674 \\
\hline
\end{tabular}


Table 3: Life style characteristics of patients with or without hypertension.

\begin{tabular}{|c|c|c|c|}
\hline Variable & Patients without HTN (N = 444) n (\%) & Patients with HTN (N=556) n (\%) & P-value $^{a}$ \\
\hline \multicolumn{4}{|l|}{ Residential area } \\
\hline Rural & $294(66.2)$ & $351(63.1)$ & Ref \\
\hline Urban & $150(33.8)$ & $205(36.9)$ & 0.319 \\
\hline \multicolumn{4}{|l|}{ Drinking of Alcohol } \\
\hline No & $387(87.2)$ & $449(80.8)$ & Ref \\
\hline Yes & $57(12.8)$ & $107(19.2)$ & 0.007 \\
\hline \multicolumn{4}{|l|}{ Smoking Status } \\
\hline No & $381(85.8)$ & $428(77.0)$ & Ref \\
\hline Yes & $63(14.2)$ & $128(23.0)$ & 0.0005 \\
\hline \multicolumn{4}{|l|}{ Food Habits (Diet) } \\
\hline Vegetarian & $36(8.1)$ & $51(9.2)$ & Ref \\
\hline Mixed (Vegetarian \& Non-vegetarian) & 408 (91.9) & $505(90.8)$ & 0.574 \\
\hline \multicolumn{4}{|l|}{ Frequency of taking Tea per day } \\
\hline Not even once & $142(32.0)$ & $146(26.3)$ & Ref \\
\hline Once & $80(18.0)$ & $94(16.9)$ & 0.502 \\
\hline Twice or more & $222(50.0)$ & $316(56.8)$ & 0.027 \\
\hline \multicolumn{4}{|l|}{ Frequency of taking coffee per day } \\
\hline Not even once & $352(79.3)$ & $417(75.0)$ & Ref \\
\hline Once & $44(9.9)$ & $71(12.8)$ & 0.133 \\
\hline Twice or more & $48(10.8)$ & $68(12.2)$ & 0.423 \\
\hline \multicolumn{4}{|l|}{ Frequency of taking Fruits per week } \\
\hline Not even once & $38(8.6)$ & $67(12.1)$ & Ref \\
\hline Once & $111(25.0)$ & $141(25.3)$ & 0.195 \\
\hline Twice & $145(32.6)$ & $164(29.5)$ & 0.068 \\
\hline Thrice or more & $98(22.1)$ & $120(21.6)$ & 0.149 \\
\hline Occasionally & $52(11.7)$ & $64(11.5)$ & 0.218 \\
\hline \multicolumn{4}{|l|}{ Frequency of Soft drinks per week } \\
\hline Not taking & $279(62.8)$ & $386(69.4)$ & Ref \\
\hline Once & $41(9.2)$ & $31(5.6)$ & 0.017 \\
\hline Twice & $07(1.6)$ & $15(2.7)$ & 0.386 \\
\hline Thrice or more & $03(0.7)$ & $11(2.0)$ & 0.171 \\
\hline Occasionally & $114(25.7)$ & $113(20.3)$ & 0.036 \\
\hline \multicolumn{4}{|l|}{ Frequency of Junk foods per week } \\
\hline Not taking & $213(48.0)$ & $289(52.0)$ & Ref \\
\hline Once & $112(25.2)$ & $93(16.7)$ & 0.003 \\
\hline Twice & $19(4.3)$ & $26(4.7)$ & 1.000 \\
\hline Thrice and more & $01(0.2)$ & $24(4.3)$ & $<0.0001$ \\
\hline Occasionally & $99(22.3)$ & $124(22.3)$ & 0.626 \\
\hline \multicolumn{4}{|l|}{ Stress at work place } \\
\hline No & $159(35.8)$ & $191(34.4)$ & Ref \\
\hline Yes & $285(64.2)$ & $365(65.6)$ & 0.640 \\
\hline \multicolumn{4}{|l|}{ Physical Activity } \\
\hline Active & $196(44.1)$ & $140(25.2)$ & Ref \\
\hline Inactive & $248(55.9)$ & $416(74.8)$ & $<0.0001$ \\
\hline
\end{tabular}


Table 4: Drug utilization pattern of antihypertensive agents in mono and combination therapies.

\begin{tabular}{cc} 
Therapy & $\mathbf{N},(\%)$ \\
\hline Monotherapy & $\mathbf{2 6 9 ( 3 8 . 6 3 )}$ \\
\hline Angiotensin Receptor Blockers (ARBs) & $100(17.98)$ \\
Calcium Channel Blockers (CCBs) & $56(10.07)$ \\
B-blockers & $35(6.29)$ \\
Diuretics & $13(2.33)$ \\
a-agonists & $6(1.07)$ \\
Angiotensin Converting Enzyme (ACE) Inhibitors & $5(0.89)$ \\
Double Combination & $\mathbf{2 0 1 ( 3 6 . 1 1 )}$ \\
\hline ARBs + Diuretics & $137(24.64)$ \\
ARBs + $\beta$-blockers & $21(3.77)$ \\
CCBs + $\beta$-blockers & $20(3.59)$ \\
ARBs + CCBs & $11(1.97)$ \\
$\beta$-blockers + Diuretics & $8(1.43)$ \\
ACE Inhibitors + Diuretics & $4(0.71)$ \\
Triple Combination & $\mathbf{3 8}(\mathbf{6 . 8})$ \\
\hline CCBs + ARBs + Diuretics & $20(3.59)$ \\
ARBs + Diuretics + Diuretics & $8(1.43)$ \\
ARBs + Diuretics + $\beta$-blockers & $8(1.43)$ \\
CCBs + Diuretics + $\beta$-blockers & $2(0.35)$ \\
Four Drug Combination & $\mathbf{1 2}(\mathbf{2 . 1 4})$ \\
ARBs + Diuretics + $\beta$-blockers + CCBs & $8(1.43)$ \\
Diuretics + CCBs + ARBs + Diuretics & $4(0.71)$ \\
Combination with other drugs & $\mathbf{8 5 ( 1 5 . 2 )}$ \\
\hline
\end{tabular}

\section{DISCUSSION}

HTN currently affects about one billion people worldwide ${ }^{8}$ and it is estimated that this could increase to 1.56 billion people by $2025 .{ }^{9}$ Most of the developing countries including India report a marked increase in the prevalence of HTN. ${ }^{10}$ India already has the second largest number of people in the world with diabetes 11 and the prevalence of HTN is also rising. ${ }^{12}$ Hypertension depends on the gender of the patient. Zhao et al. (2015) reported that the prevalence of hypertension was slightly higher in females $(52 \%, \mathrm{P}=0.978)$ than in males $(42 \%) .{ }^{13}$ Another study results are correlated with Zhao et al. (2015). They reported that the prevalence was higher in females $(14.3 \%, \mathrm{P}=0.81)$ than in males $(13.8 \%) .14 \mathrm{In}$ the present study also the hypertension prevalence was significantly higher in females $(51.8 \%, \mathrm{P}=0.048)$ than in males $(48.2 \%)$. There is a direct proportional relationship between the increase in age and the presence of hypertension. Previous studies reported that the hypertension prevalence was at $45.5 \pm 16.1$ and $54 \pm 15$ years, respectively. ${ }^{15,16}$ In the present study the mean \pm SD age was $57 \pm 11.46$ years in hypertension $(\mathrm{P}=0.03)$.
Arjun et al. (2014) reported that the prevalence of hypertension was significantly higher in married people $(81.6 \%)$ when compared to unmarried. ${ }^{17}$ Hypertension prevalence was higher in married people in the present study $(99.6 \%, P<0.0001)$. The prevalence of hypertension was higher in literates. ${ }^{17,18}$ The present study results also agreed that prevalence was higher in education (above 10th standard, 59.5\%). Family history plays a major role in the prevalence of hypertension. ${ }^{19}$ The prevalence was higher with known family history in the present study $(8.3 \%$, $P<0.001)$. Bhansali et al. (2015) reported that the prevalence of hypertension was higher in BMI $(>25$ $\mathrm{kg} / \mathrm{m}) .{ }^{1}$ In the present study also the prevalence was higher in BMI $\left(>25 \mathrm{~kg} / \mathrm{m}^{2}, P<0.0009\right)$. Hypertension prevalence was higher in upper class people $(18.9 \%, P<0.001)$ when compared to lower class $(7.8 \%) .{ }^{18}$ The present study results revealed that the hypertension was more prevalent in upper class people $(34.5 \%, P<0.001)$. Hypertension prevalence was significantly higher in diabetes $(25.6 \%, P<0.0001)$ and cardiovascular $(17.1 \%, P<0.001)$ diseases. ${ }^{16}$ Another study also supported that the diabetes (24.6\%) and cardiovascular diseases (4.9\%) are sig- 
nificantly associated with hypertension..$^{20}$ The present study results also revealed that the hypertension prevalence was higher in diabetes $(38 \%, P<0.0001)$ and cardiovascular $(11.7 \%, P<0.0001)$.

The prevalence of hypertension was higher in urban population when compared to rural in India. Alcohol was significantly associated with the prevalence of hypertension in India. ${ }^{1}$ MacMohan et al (1987) reported that the significant increase of blood pressure over time in heavy alcohol consumers ${ }^{21}$ while in the present study, the prevalence of hypertension was higher in alcoholics $(19.2 \%, P<0.007)$ compared to non-alcoholics (12.8\%). Bhansali et al. (2015) reported that the hypertension prevalence was higher in smokers in India. ${ }^{1}$ Smoking $(10.2 \%$, $P<0.05)$ was significantly associated with hypertension. ${ }^{20}$ In the present study, the prevalence of hypertension was significant in smokers $(23.0 \%$, $\mathrm{P}=0.0005)$ when compared to non-smokers $(14.2 \%)$. Mixed diet people (99.4\%) are significantly associated with the hypertension prevalence when compared to vegetarians. ${ }^{17}$ About $90.8 \%$ hypertensive patients are mixed diet people in the present study. Tea and coffee are not significantly associated with the prevalence of hypertension. ${ }^{22}$ In the present study also these are not significantly associated with hypertension. Fruits and soft drinks are significantly associated with the prevalence of hypertension. ${ }^{23}$ But in the present study these are not significantly associated with the hypertension prevalence.

The overall goal of treating hypertension is to reduce hypertension associated morbidity and mortality. ${ }^{24}$ The Seventh Report of the JNC on the Detection, Evaluation, and Treatment of High Blood Pressure is the most prominent evidence-based clinical guideline for the management of hypertension, supplemented by the 2007 American Heart Association (AHA) Scientific Statement on the treatment of hypertension. As per 2007 AHA guidelines, ACEIs, ARBs, CCBs, thiazide diuretic, or a two-drug combination are recommended for first-line therapy for stage 1 and stage 2 hypertension. ${ }^{25}$ This is in contrast to the JNC-7 guidelines that placed preference on using a thiazide diuretic over other agents for most patients, and also included a $\beta$-blocker as a potential first-line option followed by ACEIs, ARBs, CCBs, and thiazide diuretics. ${ }^{26}$ The overall rate of adherence was $24.9 \%$ (Pre hypertension, $P<0.01$ ); $80.3 \%$ (Stage 1 hypertension, $P<0.001$ ); 73.93\% (Stage 2 hypertension) and 50\% (Hypertension emergency) in the present study. Previous studies show that a simple evidence-based guideline appears to be effective in raising the quality of antihypertensive ther- apy in United States of America ${ }^{27}$ and China. ${ }^{28}$ The present study results revealed that the physicians in south Indian hospitals are strictly following the evidence based guidelines (JNC-7) to improve the patient care like America and China.

Age is the major risk factor for hypertension. Reddy et al. reported that the prevalence of hypertension was significantly associated with the age above 40 years (odds ratio: 30.2, 95\% confidence interval: 26.3-34.1). ${ }^{29}$ The present study results also suggested that the age above 40 years was the significant risk factor for hypertension (odds ratio: 3.368, 95\% confidence interval: 2.449-5.405, $P<0.0001)$. Marriage is the significant risk factor in hypertension. Married people (odds ratio: 13.462, 95\% confidence interval: 1.818-100, $\mathrm{P}=0.011$ ) are extremely associated with hypertension when compared to unmarried people. ${ }^{30}$ The present study results are also supported that married people (odds ratio: 13.13 , 95\% confidence interval: $3.059-56.31, P<0.0001)$ are more risk at hypertension. Being widower (odds ratio: $3.20,95 \%$ confidence interval: $1.05-3.35)$ is the significant risk factor for hypertension. ${ }^{31}$ Panesar et al. reported that the widowed are significantly associated with the hypertension (odds ratio: 14.86, 95\% confidence interval: $1.187-200, \mathrm{P}=0.036) .{ }^{30}$ The present study results also revealed that the risk (odds ratio: 101.5, 95\% confidence interval: 15.55-662.3, $P<0.0001)$ was significantly higher the widowed of south Indian population.

Literate (odds ratio: 0.83, 95\% confidence interval: $0.70-0.99, \mathrm{P}=0.03$ ) was not significantly risk factor of hypertension..$^{32}$ In the present study also it was not significantly associated with the hypertension (odds ratio: $0.781,95 \%$ confidence interval: 0.603 $1.022, \mathrm{P}=0.066)$. Greater the BMI $\left(\geq 27.50 \mathrm{~kg} / \mathrm{m}^{2}\right)$, more the risk (odds ratio: $5.14,95 \%$ confidence interval: 3.89-6.80) of hypertension in the south Indian population. ${ }^{31}$ Panesar et al. (2013) reported that the BMI ( $\geq 25 \mathrm{~kg} / \mathrm{m} 2)$ is significantly associated with the hypertension (odds ratio: $6.801,95 \%$ confidence interval: $0.868-52.63, \mathrm{P}=0.068) .{ }^{30}$ The present study results also indicated that the $\mathrm{BMI}$ (odds ratio: 1.529, 95\% confidence interval: 1.189-1.967, $\mathrm{P}=0.0009$ ) as the risk for hypertension. Family history is the major risk factor for hypertension. The risk was higher in both parents (odds ratio: 3.614, 95\% confidence interval: 1.348-9.709, $\mathrm{P}=0.011)$ are known hypertensive than one parent (odds ratio: 0.401, 95\% confidence interval: $0.149-1.075, \mathrm{P}=0.069)$ positive. 30 The prevalence of hypertension (odds ratio: 1.76, 95\% confidence interval: 1.45-2.14, $P<0.05$ ) was higher in known family history of hyperten- 


\begin{tabular}{|c|c|c|c|c|}
\hline Hypertension type & Recommendations & Adherence rate (\%) & $\begin{array}{c}\text { Non-Adherence rate } \\
(\%)\end{array}$ & P-Value \\
\hline Pre Hypertension & No drug indicated & 24.9 & 75.1 & $P<0.01$ \\
\hline \multicolumn{2}{|c|}{ Stage 1 Hypertension } & 80.3 & 19.7 & $P<0.001$ \\
\hline \multicolumn{5}{|c|}{$\begin{array}{l}\text { Thiazide type Diuretics } \\
\text { for most }\end{array}$} \\
\hline \multicolumn{5}{|c|}{ For many consider } \\
\hline & ACEls & 4.0 & & \\
\hline & ARBs & 43.8 & & \\
\hline & BBs & 11.3 & & \\
\hline & CCBs & 16.3 & & \\
\hline & Other & 4.9 & & \\
\hline Stage 2 & ertension & 73.93 & 26.07 & $P<0.001$ \\
\hline \multicolumn{5}{|c|}{$\begin{array}{c}\text { Drug Combinations for } \\
\text { most }\end{array}$} \\
\hline \multicolumn{5}{|c|}{ (Usually thiazide type ) } \\
\hline & ACEls + Diuretics & 13.3 & & \\
\hline & ARBs + Diuretics & 42.19 & & \\
\hline & BBs + Diuretics & 6.64 & & \\
\hline & CCBs + Diuretics & 4.8 & & \\
\hline & Other combinations & 7.0 & & \\
\hline Hypertens & Emergency & 50 & 50 & $P<0.05$ \\
\hline & Nifedipine SL & 9 & & \\
\hline & Furosemide i.v. & 12.8 & & \\
\hline & Metoprolol i.v. & 28.2 & & \\
\hline
\end{tabular}

ARBs, Angiotensin Recerptor Blockers; CCBs, Calcium Channel Blockers; BBs, $\beta$-blockers; ACEls, Angiotensin Converting Enzyme Inhibitors.

Table 6: Modifiable and nonmodifiable risk factors for hypertension in univariate regression analysis.

\begin{tabular}{ccc}
\hline Variable & OR (95\% Cl) & P-value \\
\hline Age & $3.638(2.449-5.405)$ & $<0.0001$ \\
Between 41- 60 years & $5.689(3.693-8.763)$ & $<0.0001$ \\
Above 60 years & $1.287(1.002-1.653)$ & 0.048 \\
Female gender & $13.13(3.059-56.31)$ & $<0.0001$ \\
Married & $101.5(15.55-66.23)$ & $<0.0001$ \\
Widowed & $0.781(0.603-1.012)$ & 0.066 \\
Educated (Above 10th standard) & $1.529(1.189-1.967)$ & 0.0009 \\
Body mass index (>25 kg/m2) & $4.677(3.281-6.666)$ & $<0.0001$ \\
Monthly income (Above Rs. 10,000) & $1.698(1.150-2.507)$ & 0.009 \\
\hline Family history & $2.816(1.675-4.732)$ & $<0.0001$ \\
\hline Father & $3.238(1.747-6.001)$ & $<0.0001$ \\
Mother & $1.071(0.596-1.925)$ & 0.881 \\
\hline Father \& mother & & $<0.0001$ \\
Brother \& sister & $6.695(4.038-11.10)$ & 0.006 \\
\hline Co-morbidities & $3.830(1.393-10.53)$ &
\end{tabular}




\begin{tabular}{|c|c|c|}
\hline Thyroid disorders & $1.031(0.242-4.393)$ & 1.000 \\
\hline Diabetes and CVDs & $1.985(1.121-3.513)$ & 0.022 \\
\hline Diabetes and Thyroid & $2.750(1.357-5.572)$ & 0.007 \\
\hline Diabetes and other & $1.747(1.045-2.920)$ & 0.041 \\
\hline $\begin{array}{l}\text { CVD and other co-morbid } \\
\text { conditions }\end{array}$ & $13.41(6.093-29.50)$ & $<0.0001$ \\
\hline PCOD & $1.031(0.288-3.682)$ & 1.000 \\
\hline Chronic Kidney Disease & $10.83(3.429-34.19)$ & $<0.0001$ \\
\hline Urban residence & $1.145(0.881-1.487)$ & 0.319 \\
\hline Physically inactivity & $1.906(0.930-1.538)$ & $<0.0001$ \\
\hline $\begin{array}{l}\text { Mixed (Vegetarian and non- } \\
\text { vegetarian) }\end{array}$ & $0.026(0.017-0.039)$ & $<0.0001$ \\
\hline Alcohol & $1.809(1.298-2.520)$ & 0.0076 \\
\hline Smoking & $1.066(0.820-1.385)$ & 0.0005 \\
\hline Stress & $1.235(0.652-1.604)$ & 0.640 \\
\hline Fruits & $0.671(0.442-1.021)$ & 0.063 \\
\hline \multicolumn{3}{|l|}{ Tea \& Coffee } \\
\hline Daily once tea & $1.215(0.770-1.915)$ & 0.419 \\
\hline Daily twice tea & $1.464(0.987-2.169)$ & 0.070 \\
\hline Daily thrice \& even more tea & $1.146(0.709-1.850)$ & 0.625 \\
\hline Daily once coffee & $1.591(0.948-2.671)$ & 0.089 \\
\hline Daily twice coffee & $1.122(0.651-1.930)$ & 0.782 \\
\hline Daily thrice coffee & $2.870(0.871-9.445)$ & 0.102 \\
\hline Tea \& coffee daily once & $2.609(0.781-8.713)$ & 0.160 \\
\hline Tea \& coffee daily twice & $1.043(0.203-5.349)$ & 1.000 \\
\hline $\begin{array}{l}\text { Tea \& coffee daily thrice \& even } \\
\text { more }\end{array}$ & $1.739(0.400-7.559)$ & 0.494 \\
\hline \multicolumn{3}{|l|}{ Soft drinks } \\
\hline Soft drinks (weekly once) & $0.546(0.334-0.893)$ & 0.017 \\
\hline Soft drinks (weekly twice) & $1.549(0.623-3.850)$ & 0.386 \\
\hline Soft drinks (weekly thrice or more) & $2.650(0.732-9.591)$ & 0.123 \\
\hline Soft drinks (Occasionally) & $0.716(0.529-0.969)$ & 0.036 \\
\hline \multicolumn{3}{|l|}{ Junk foods } \\
\hline Weekly once & $0.612(0.441-0.848)$ & 0.003 \\
\hline Weekly twice & $1.009(0.543-1.870)$ & 1.000 \\
\hline Weekly thrice and more & $17.69(2.373-131.8)$ & $<0.0001$ \\
\hline Occasionally & $0.923(0.671-1.269)$ & 0.626 \\
\hline
\end{tabular}

sion. ${ }^{33}$ In the present study also family history (father, odds ratio: $1.698,95 \%$ confidence interval: 1.150-2.507, $\mathrm{P}=0.009$; mother, odds ratio: 2.816 , 95\% confidence interval: 1.675-4.732, $P<0.0001$; both father and mother, odds ratio: $3.238,95 \%$ confidence interval: $1.747-6.001, P<0.0001)$ was the major risk factor. Diabetes mellitus (odds ratio: 6.9, 95\% confidence interval: 5.5-8.7) was the significant risk factor in hypertension. ${ }^{29}$ In the present study also it was a risk factor for hypertension.

Physical inactivity (odds ratio: $2.21,95 \%$ confidence interval: $1.51-3.24, P<0.0001)$ was a significant risk factor for hypertension.16 Another study also reported that physical inactivity (odds ratio: 1.59, 95\% confidence interval: $1.02-2.47, \mathrm{P}=0.04)$ was the risk factor of hypertension.20 In the present study also physical inactivity (odds ratio: $1.906,95 \%$ confidence interval: $0.930-1.538, P<0.0001)$ significantly contributed to hypertension. Alcohol consumption (odds ratio: 1.64, 95\% confidence interval: 1.51-1.78, $P<0.05)$ is the significant risk factor in hypertension. ${ }^{15}$ The risk of hypertension was increased with alcohol (odds ratio: 1.21, 95\% confidence interval: 0.74-1.38, $P<0.05)$ consumption.16 The present 
study results are also suggested that the alcohol consumption (odds ratio: 1.618, 95\% confidence interval: $1.141-2.294, \mathrm{P}=0.0076)$ was the risk factor for hypertension. Smoking (odds ratio: $1.66,95 \%$ confidence interval: $1.10-2.52, \mathrm{P}=0.016)$ was the risk factor for hypertension. ${ }^{16}$ Reddy et al reported that the smoking was the risk factor in hypertension (odds ratio: $3.8,95 \%$ confidence interval: 3.1-4.6). ${ }^{29}$ The present study results were also correlated with the smoking (odds ratio: $1.809,95 \%$ confidence interval: $1.298-2.520, \mathrm{P}=0.0005)$ as the risk factor for hypertension.

Stress is a significant risk factor for hypertension, but in the present study it was not significantly associated with hypertension (odds ratio: 1.235, 95\% confidence interval: $0.652-1.604, \mathrm{P}=0.640)$. It was supported by the previous study. ${ }^{22}$ They found that stress (odds ratio: 0.592, 95\% confidence interval: 0.478-0.732) was not significantly associated with the hypertension. Fruits and soft drinks are significant risk factors for hypertension. ${ }^{23}$ Ram et al. (2011) reported that the fruit, vegetable and legume intake were inversely associated with hypertension (females, odds ratio: $-2.15,95 \%$ confidence interval: 1.82-2.35; males, odds ratio: $-2.18,95 \%$ confidence interval: 1.88-2.41).15 In the present also fruit consumption (odds ratio: $0.671,95 \%$ confidence interval: $0.442-1.021, P=0.063$ ) was not significantly associated with hypertension. But in the present study these are not significantly associated with the hypertension. Tea (odds ratio: 1.450, 95\% confidence interval: 1.090-1.930) and coffee (odds ratio: 0.970, 95\% confidence interval: $0.742-1.313$ ) are not significant risk factors for hypertension.22 In the present study also these are not significant risk factors for hypertension (Table 6). Junk food (weekly thrice or more) intake (odds ratio: 17.69, 95\% confidence interval: $2.373-131.8, P<0.0001)$ were significantly associated with HTN.

\section{CONCLUSION}

The present study results indicated that the physicians are strictly following the JNC-7 guidelines to prescribe antihypertensive agents, because the medication adherence was optimal in all the types of hypertension. Junk foods, age (above 40 years), diabetes, alcohol, smoking, marital status and high economic status are the main risk factors for hypertension.

\section{ACKNOWLEDGEMENTS}

This study was supported by Siddhartha Academy of General and Technical Education (SAGTE). The authors are grateful to the physicians of Dr. Pinnamaneni Siddhartha Institute of Medical Sciences and Research Foundation, Vijayawada, Andhra Pradesh for providing necessary information. The authors thank N. Venkateswarlu, President and P. Lakshmana Rao, Secretary of SAGTE for providing necessary facilities.

\section{KEY FINDING}

Hypertension prevalence was significantly higher in females compared to males $(P<0.048)$.

Diabetes mellitus (38.0\%) was the major co-morbidity with hypertension followed by cardiovascular diseases (14.7\%).

Age, family history, BMI, socioeconomic status, alcohol, smoking and junk foods are significantly associated with hypertension.

Angiotensin receptor blockers (17.98\%) are most widely used drugs in monotherapy (38.63\%) followed by calcium channel blockers (10.07\%).

In double combination therapy (36.11), the most commonly prescribed combination was angiotensin receptor blockers + diuretics (24.64\%).

According to JNC-7 guidelines, the overall rate of medication adherence was $24.9 \%$ (prehypertension, $P<0.01$ ), $80.3 \%$ (stage 1 hypertension, $P<0.001$ ), $73.93 \%$ (stage 2 hypertension, $P<0.001$ ) and $50 \%$ (hypertension emergency, $P<0.05$ ).

Junk foods (weekly thrice or more), diabetes mellitus, chronic kidney disease, cardiovascular diseases, family history, socioeconomic status, age, alcohol, smoking, BMI and physical inactivity are the major risk factors for hypertension.

\section{SOURCE OF FUNDING}

Self funded (authors not received funding from any other funding source for this work).

\section{CONFLICT OF INTEREST}

The authors declare that this research does not have any conflict of interest with anyone or any Institute.

\section{ABBREVIATION USED}

HTN: Hypertension; JNC-7: Joint National Committee-7; AHA: American Heart Association; ACC: American College of Cardiology; CDC: Centers for Disease Control and Prevention; ADA: American 
Diabetes Association; ESH: European Society of Hypertension; ESC: European Society of Cardiology; ACEIs: Angiotensin Converting Enzyme Inhibitors; ARBs: Angiotensin Receptor Blockers; CCBs: Calcium Channel Blockers; SBP: Systolic Blood Pressure; DBP: Diastolic Blood Pressure; CVDs: Cardiovascular Diseases; PCOS: Poly Cystic Ovarian Syndrome.

\section{REFERENCES}

1. Bhansali A, Dhandania VK, Deepa M, Anjana RM, Joshi SR, Joshi PP, et al. Prevalence of and risk factors for hypertension in urban and rural India: the ICMR-INDIAB study. Journal of Human Hypertension 2015;29:204-209. https://doi.org/10.1038/jhh.2014.57; PMid:25078490.

2. World Health Organization. Global status report on noncommunicable diseases 2010: description of the global burden of NCDs, their risk factors and determinants 2011, pp 16.

3. Joshi SR, Saboo B, Vadivale M, Dani SI, Mithal A, et al. Prevalence of diagnosed and undiagnosed diabetes and hypertension in India-results from the Screening India's Twin Epidemic (SITE) study. Diabetes technology \& therapeutics. 2012;14(1):8-15. https://doi.org/10.1089/dia.2011.0243; PMid:22050271.

4. Staessen JA, Wang JG, Thijs L. Cardiovascular protection and blood pressure reduction: a meta-analysis. The Lancet. 2001;358(9290):1305-15. https://doi. org/10.1016/S0140-6736(01)06411-X.

5. Go AS, Bauman MA, Coleman King SM, Fonarow GC, Lawrence W, Williams KA, Sanchez E. An effective approach to high blood pressure control: a science advisory from the American Heart Association, the American College of Cardiology, and the Centers for Disease Control and Prevention. J Am Coll Cardiol. 2014;63:1230-1238. https://doi.org/10.1016/j.jacc.2013.11.007; PMid:24246165.

6. James PA, Oparil S, Carter BL, Cushman WC, Dennison-Himmelfarb C, et al. 2014 evidence-based guideline for the management of high blood pressure in adults: report from the panel members appointed to the Eighth Joint National Committee (JNC 8). Jama. 2014;311(5):507-20. https://doi.org/10.1001/ jama.2013.284427; PMid:24352797.

7. Chobanian AV, Bakris GL, Black HR, Cushman WC, Green LA, Izzo JL Jr. The seventh report of the Joint National Committee on Prevention, Detection, Evaluation and Treatment of High Blood Pressure (JNC-7). JAMA 2003;289: 2560-2572. https://doi.org/10.1001/jama.289.19.2560; PMid:12748199.

8. Chobanian AV, Bakris GL, Black HR, Cushman WC, Green LA, Izzo JL Jr. Seventh report of the Joint National Committee on Prevention, Detection, Evaluation, and Treatment of High Blood Pressure. Hypertension 2003;42:12061252. https://doi.org/10.1161/01.HYP.0000107251.49515.c2; PMid:14656957.

9. Kearney PM, Whelton M, Reynolds K, Muntner P, Whelton PK, He J. Global burden of hypertension: analysis of worldwide data. The lancet. 2005;365(9455):217-23. https://doi.org/10.1016/S0140-6736(05)70151-3.

10. Reddy KS. Hypertension control in developing countries: generic issues. Journal of human hypertension. 1996;10:S33-8. PMid:8965285.

11. Unwin N, Whiting D, Guariguata L, Ghyoot G, Gan D (eds). Diabetes Atlas, 5th edn. International Diabetes Federation: Brussels, 2011, pp 11-74.

12. Joshi SR, Parikh RM. India - Diabetes Capital of the World: now heading towards hypertension. J Assoc Physicians India 2007;55:323-324. PMid:17844690.

13. Yue Z, Bin W, Weilin Q, Aifang Y. Effect of medication adherence on blood pressure control and risk factors for antihypertensive medication adherence. Journal of evaluation in clinical practice. 2015;21(1):166-72. https://doi. org/10.1111/jep.12268; PMid:25318567.

14. Kishore J, Gupta N, Kohli C, Kumar N. Prevalence of hypertension and determination of its risk factors in rural Delhi. International journal of hypertension. 2016. https://doi.org/10.1155/2016/7962595; PMid:27127646 PMCid:PMC4834167.

15. Ram BS. Prevalence and risk factors for prehypertension and hypertension in five Indian cities. Acta Cardiol 2011;66:29-37. https://doi.org/10.1016/00029149(90)91261-4.
16. Shanthirani CS, Pradeepa R, Deepa R, Premalatha G, Saroja R, Mohan V. Prevalence and risk factors of hypertension in a selected South Indian population--the Chennai Urban Population Study. The Journal of the Association of Physicians of India. 2003;51:20-7. PMid:12693449.

17. Lakshman A, Manikath N, Rahim A, Anilakumari VP. Prevalence and risk factors of hypertension among male occupational bus drivers in North Kerala, South India: A Cross-sectional Study. ISRN preventive medicine. 2014. https:// doi.org/10.1155/2014/318532; PMid:24971195 PMCid:PMC4045462.

18. Ajeet SB, Pradeep KK, Neelam AT, Pooja B, Sambit P, Vikrant K. Prevalence of hypertension and associated cardiovascular risk factors in Central India. J Family Community Med 2014;21:29-38. https://doi.org/10.4103/22308229.128775; PMid:24695988 PMCid:PMC3966094.

19. Islam SM, Mainuddin AK, Islam MS, Karim MA, Mou SZ, et al. Prevalence of risk factors for hypertension: A cross-sectional study in an urban area of Bangladesh. Global Cardiology Science and Practice. 2015 Nov 20:43. https:// doi.org/10.5339/gcsp.2015.43; PMid:26779518 PMCid:PMC4710872.

20. Yadav S, Boddula R, Genitta G, Bhatia V, Bansal B, et al. Prevalence \& risk factors of pre-hypertension \& hypertension in an affluent north Indian population. Indian Journal of Medical Research. 2008;128(6):712. PMid:19246794.

21. MacMohan S. Alcohol Consumption and Hypertension. Hypertension 1987;9:111-121. https://doi.org/10.1161/01.HYP.9.2.111.

22. Maha MMM, Reda IEM, Hanan HEE. Prevalence of hypertension and associated risk factors among university students: Comparative study. Journal of Nursing Education and Practice 2016;6:19-27.

23. Amma GM, Vasudevan B, Akshayakumar S. Prevalence and determinants of prehypertension and hypertension among adolescents: a school based study in a rural area of Kerala, India.

24. Longo DL, Fauci SA, Kasper DL, Hauser SL, Jameson JL, Loscalzo J. Harrison's Principles of Internal Medicine. Eighteenth edition, McGraw-Hill Medical, New York, United States of America 2012.

25. Rosendorff $C$. Treatment of hypertension in the prevention and management of ischemic heart disease: a scientific statement from the American Heart Association Council for High Blood Pressure Research and the Councils on Clinical Cardiology and Epidemiology and Prevention. Circulation 2007;115:2761-2768. https://doi.org/10.1161/CIRCULATIONAHA.107.183885; PMid:17502569.

26. Sai SS, Shaik NA, Sahithi V, Haroled PPL, Ravindrababu P, Siva RC. An Assessment of Antihypertensive Drug Utilization Patterns and Adherence to JNC-7 Guidelines in South Indian Tertiary Care Teaching Hospital. Indian Journal of Pharmacy Practice 2015;8:177-182.

27. Avanzini F. Simple, shared guidelines raise the quality of antihypertensive treatment in routine care. American Heart Journal 2002;144:726-32. https://doi. org/10.1067/mhj.2002.125327; https://doi.org/10.1016/S0002-8703(02)001497.

28. Wong MC, Tam WW, Cheung CS, Tong EL, Sek AC, et al. Medication adherence to first-line antihypertensive drug class in a large Chinese population. International journal of cardiology. 2013;167(4):1438-42. https:// doi.org/10.1016/j.ijcard.2012.04.060; PMid:22560948.

29. Reddy SS, Prabhu GR. Prevalence and risk factors of hypertension in adults in an Urban Slum, Tirupati, AP. Indian Journal of community medicine. 2005;30(3):84. https://doi.org/10.4103/0970-0218.42855.

30. Panesar S, Chaturvedi S, Saini NK, Avasthi R, Singh A. Prevalence and predictors of hypertension among residents aged 20-59 years of a slumresettlement colony in Delhi, India. WHO South-East Asia Journal of Public Health. 2013;2(2):83. https://doi.org/10.4103/2224-3151.122937.

31. Kaur P, Rao SR, Radhakrishnan E, Rajasekar D, Gupte MD. Prevalence, awareness, treatment, control and risk factors for hypertension in a rural population in South India. International journal of public health. 2012;57(1):8794. https://doi.org/10.1007/s00038-011-0303-3. PMid:21947549.

32. Hazarika NC, Narain K, Biswas D, Kalita HC, Mahanta J. Hypertension in the native rural population of Assam. Natl Med J India. 2004;17(6):300-4. PMid:15736549.

33. Tsutsumi A, Kayaba K, Tsutsumi K, Igarashi M. Association between job strain and prevalence of hypertension: a cross sectional analysis in a Japanese working population with a wide range of occupations: the Jichi Medical School cohort study. Occupational and environmental medicine. 2001;58(6):367-73. https://doi.org/10.1136/oem.58.6.367; PMid:11351051 PMCid:PMC1740148. 